\title{
公的賃貸集合住宅団地の住環境に対する住民評価の構造分析 \\ A STRUCTURAL ANALYSIS ON RESIDENTS' EVALUATION FOR RESIDENTIAL ENVIRONMENT IN AND AROUND PUBLIC APARTMENT HOUSES COMPLEXES
}

\author{
横田隆司*, 柏原士郎**, 吉村英祐*, 飯田 匡***, 劉 䑣 䑣**** \\ Takashi YOKOTA, Shiro KASHIHARA, Hidemasa YOSHIMURA, \\ Tadasu IIDA and Tongtong LIU
}

\begin{abstract}
This research aims at analyzing residents' evaluation for residential environment in and around rental apartment houses complexes built by OSAKA Prefectural Housing Corporation by using covariance structure analysis with the questionnaire survey data. After comparing the result of analyzing twelve items by using multi-regression analysis and covariance structure analysis, and the intermediate effect of physical environment on total evaluation, the viability of the model made from covariance structure analysis was tested. It is found out that the models by sex were not valid on evaluation for residential environment. Finally, the analysis of historical effect on residents' evaluation for residential environment by using mean-covariance structure analysis indicates that only mean factor of environment has been raised as time advances while mean value of other factors have been reduced.
\end{abstract}

Keywords: Multi dwelling houses, Questionnaire survey, Location, Covariance structure analysis 集合住宅, アンケート調查, 立地, 共分散構造分析

1.はじめに

(1) 研究の背景と目的

戦後大量に建設された公的団地再生の方向性を探ることは昨今 の重要な課題である。ただし、残念ながら自治体の財政悪化のあお りをうけて、例えば中低層棟を建て替えて高層棟にすることででき た余剩地を売り払う施策が取られようとしている等が報道されてい る。しかし、公的団地においては現在の優れている点を残しつつ、 より豊かな団地環境づくりを目指さなければならないのは言うまで もないと考える。

著者らは、前 2 報文1)，2) において大阪府住宅供給公社が管理す る貨貸集合住宅団地（以下、公社団地）を対象とし、それらの魅力 を立地特性から分析すると共に、立地特性を含めた住環境に対する 住民の評価をアンケート調查により明らかにした。すなわち、第一 報文1)では物理的環境と入居募集時の空屋率との関係を分析するこ とで, 公社団地への入居希望者が求める立地環境の整備策を、第二 報文2）では物理的環境と居住者による住環境評価との関係を探るこ とで，既入居者が求める住環境の整備策をそれそれ考察した。これ らのことから公社団地の持つ魅力を入居時と居住時という $2 つ の$ 時 点での評価から捉える枠組みを作ることができたと考える。

さて本諭文は、それらの継続研究として公社団地居住者の住環境

評価をさらに掘り下げて分析することを目的としている。すなわち、 第二報のアンケート調查で得られた居住者による住環境評価データ を用いて、共分散構造分析により住環境評価の構造化をはかり、さ まざま住環境要素が直接、団地の魅力に直結するのではなく、その 背後にある心理的な評価構造を通して，住民が住環境の魅力を評価 というモデルを作成して考察しようとするものである。

なお、共分散構造分析は他分野での先行研究は数多いが、建築計 画の分野では多変量解析手法としての適用性はまだまだ未知数であ ると言ってよい。その意味で、共分散構造分析に着目し、その分析 手法の適用性についての知見を得ることも研究の目的としている。

\section{(2) 既往の研究}

住民の評価構造を分析した研究には、古くは梶文8)の生活環境に 対する住民満足感を因子分析により構造化して，本論文と同じく住 環境の評価を試みた先駆的研究がある。最近では原田ら文9)が居住 環境に対する住民意識の 13 年間の変化を因子分析等により分析し ており，本論文でも取り上げている意識構造の時間的変化を捉えよ うとした先駆的研究と言える。その他，因子分析を用いた同様の研 究は数多いが，共分散構造分析まで試みた研究はまだまだ少ない。 その中で、共分散構造分析を用いて住民の評価構造を探ろうとした

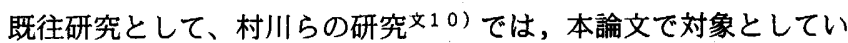

大阪大学大学院工学研究科建築工学専攻 助教授 · 博士 (工学)

** 大阪大学大学院工学研究科建築工学専攻 教授. 工博

*** 大阪大学大学院工学研究科建築工学専攻 助手. 博士 (工学)

**** 天津大学建筑学院 助教授 · 博士 (工学)
Assoc. Prof., Graduate School of Eng., Osaka Univ., Dr. Eng.

Prof., Graduate School of Eng., Osaka Univ., Dr. Eng. Assistant Prof., Graduate School of Eng., Osaka Univ., Dr. Eng.

Assoc. Prof., School of Architecture, Tianjin Univ., Dr. Eng. 
る一般住民ではないものの, 大学生に対象を絞り環境移行という切 り口で文9）と同様；時間的な変化を考虑した生活環境の総合評価 の分析を試みている。斎藤らの住宅団地の外部空間を分析した研究 文11)では，本論文で対象としている包括的な外部環境ではないも のの，アメニティという観点に絞って外部空間の評価構造を定量化 している。さらに、浅見らの公団住宅や住環境に対する居住者の評 価を分析した研究文12)では，本論文と同様，公的貢貸住宅居住者 を対象としながらも，〈住環境〉に加えてく住宅>自体も評価構造 モデルに加えて分析している点に特長があり，住宅の影響が大きい ことを報告している。

\section{2. 研究方法}

本研究で用いる居住者による住環境評価デー夕は第二報のアンケ 一ト調査で得られたものである。このアンケート調查は大阪府住宅 供給公社が管理する 12 団地の居住者を対象としたもので、調查内 容の詳細は前報に譲るが、その概要を表一 $1 、 2$ に示す。基本的に はさまざまな属性をもつ居住者からのデータが得られるように配布 団地を選定しており、デー夕自体もさまざまな属性をもつ居住者か らの意見であると想定される注1)。本研究では表一 1 に示す調査項 目の中から住環境評価の回答デー夕を採用した。これは、団地の住 環境を示すと考えられる 14 項目（図一1参照）を［1〜 5] の間 隔尺度の選択肢を設けて回答してもらったものである。

\begin{tabular}{|c|c|}
\hline 配布日時 & 2002年12月～2003年 1 月（各戸配布，郵送回収） \\
\hline $\begin{array}{l}\text { 配布 枚 数 } \\
\text { など }\end{array}$ & \begin{tabular}{|l} 
配布総数 \\
回収率 \\
21.639 枚, 有効回収数 549 枚
\end{tabular} \\
\hline 配布団地 & 大阪府住宅供給公社管理の 12 団地（表一 2 ) \\
\hline 内容 & $\begin{array}{l}\text { 入居理由, 定住志向, 住環境評価, 周辺施設評 } \\
\text { 価, 回答者属性 }\end{array}$ \\
\hline
\end{tabular}

分析には共分散構造分析を用いる。共分散構造分析は、因子分析 と同様、直接観測できない潜在変数を導入し、その潜在変数と観測 变数との間の因果関係を構造モデルとして組み立てる多変量解析手 法の総称であり、回帰分析や因子分析などを内包している。分析理 論としては古いが、利用可能なりフトウエアが充実してきたことで， 最近、急速に社会科学の分野で普及している手法である。共分散構 造分析の詳細については専門書文5) 7) を参照されたい。

なお，こうした統計モデルを採用する場合には，サンプリング法 の㰽当性と高い回収率を必要とし，本論文で用いている低い回収率

表一2 調查対象団地の概要

\begin{tabular}{|c|c|c|c|c|c|c|c|c|}
\hline 団地名 & 所在地 & 有効回収数(事) & 建設年 $(19 * *)$ & 平均家䨘 $(円)$ & 階数 & 平均応㐞倍率 & 平均空㕓率 & 公共交通 \\
\hline 井口堂, 同B & 池田市 & $42(21.5)$ & 59,60 & 24,350 & 4 & 4.7 & 2.33 & 阪急宝塚線 \\
\hline 茨木郡山 & 茨木市 & $31(26.1)$ & 70 & 40,350 & 12 & 9.5 & 0 & JR西日本東海道線 \\
\hline 竹見台 & 吹田市 & $59(29.2)$ & 69 & 42,800 & 12 & 53.3 & 1.13 & 北大阮急行＋地下鉄御堂筋線 \\
\hline 千里山田西 & 吹田市 & $54(18.4)$ & 77 & 77,100 & 11,14 & 9.11 & 12.36 & 阪急千里線 \\
\hline 打上 & 寝屋川市 & $75(21.1)$ & 74 & 45,340 & 5 & 4.59 & 3.6 & JR西日本学研都市線 \\
\hline 長瀨東, 同B & 東大阪市 & $90(41.7)$ & 58,59 & 24,900 & 3,4 & 7.33 & 0.46 & 近鉄大阪線 \\
\hline 金岡東H，I & 堺市 & $31(20.4)$ & 70,71 & 47,250 & 10 & 27.33 & 1.25 & 地下鉄御堂筋線 \\
\hline 戎の町 & 堺市 & $12(19.7)$ & 50 & 17,493 & 4 & 基筆停止 & 6.48 & 南海高野線 \\
\hline 浜寺·浜寺果 & 堺市 & $16(12.9)$ & 59,60 & 26,050 & 4 & 2.55 & 1.56 & 南海本線 \\
\hline 原山台 & 堺市 & $70(21.1)$ & 72 & 36,055 & 5 & 0.79 & 3.33 & 泉北离速鉄道＋南海高野線 \\
\hline 原山台B & 堺市 & $42(14.0)$ & 73 & 71,350 & 14 & 0.8 & 25.25 & 泉北高速鉄道＋南海高野線 \\
\hline 岸和田天神山 & \begin{tabular}{|l|} 
湈和田市 \\
\end{tabular} & $27(14.1)$ & 78 & 58,655 & 5 & 0.97 & 13.18 & JR西日本阪和線 \\
\hline & 合計 & $549(21.6)$ & & & & & & \\
\hline
\end{tabular}

のデー夕は検定を用いる上では大きな弱点である。すなわち, “ア ンケートに回答されなかった約 8 割の方の評価が，約 2 割の回答者 のそれと変わらない”というかなり厳しい仮定を必要とする。した がって, 本論文では共分散構造モデルを検定により検証しているが, あくまで “当該モデルが棄却されないでいる”という弱い主張のみ しか言えないという前提で論を進める。

共分散構造による分析手順の概要は以下の通りである。

\section{（1）線形モデルによる住環境評価の分析}

本報では、まず共分散構造モデルとして線形モデルを考えて、デ 一夕分析し、従来からの重回帰モデルとの比較検討を行う。併せて、 共分散構造分析は直接効果や間接効果を考虑して分析できるので、 それらを含めた結果の考察を行う。これは、物理的環境が住民の心 理的評価に影響を及ぼしているか否かを検証するものである。

（2）潜在因子モデルによる住環境評価の分析

一般的な共分散構造分析の手順により因子分析を用いて潜在変数 を抽出し、それらの潜在変数と観測変数を用いて潜在因子を想定す る構造モデルという各変数間の関係を示すモデル作成する（図一 5 参照)。次いで適合度を示す指標値により、作成した構造モデルの 適合性を検証し、問題点があれば構造モデルを修正する。

（3）属性別にみた住環境評価の分析

修正したモデルが適用可能であることを確認した上で、男女別の 分析を行い、当該グループ間の差異を検証する。さらに、居住履歴 からみた住環境評価を、平均・共分散構造分析（共分散構造分析に 平均を取り入れた分析モデル）で行うことにより、評価構造の経年 変化が捉えられるかどうか検証する。

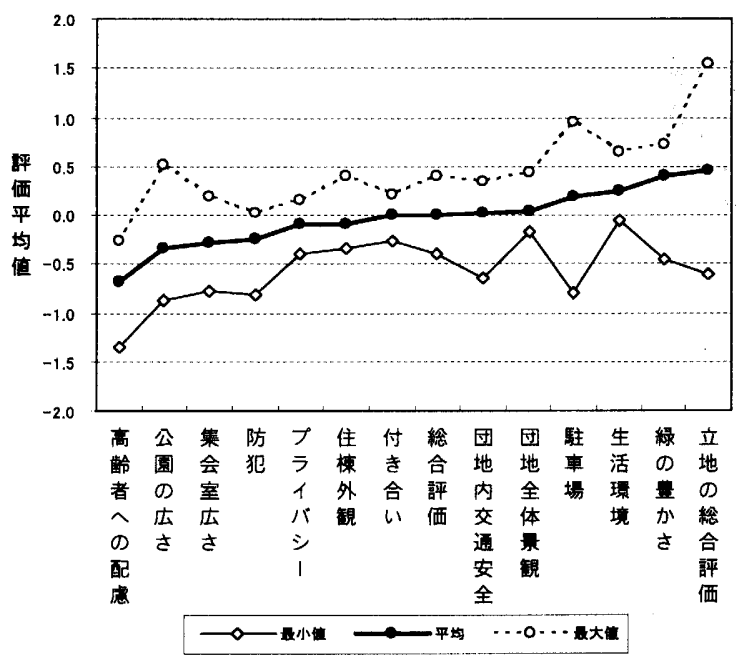

図-1 住環境評価の集計結果 


\section{3. 線形モデルによる住環境評価の分析}

\section{（1）住環境評価デー夕の概要}

団地内外の住環境に関して住民が回答した個々の評価項目を単純

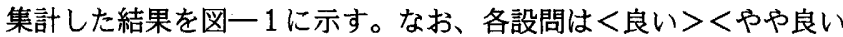

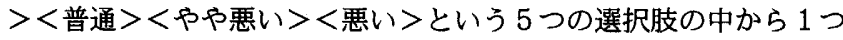
を選択してもらっているので、それらをく+2>〜<-2>の間隔

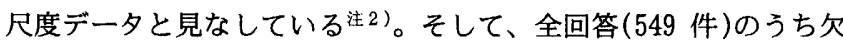
損值がないデータのみ (422 件) で集計した。

図一1を見ると公社団地の立地や緑といった団地周辺環境は評価 されているものの、防犯や高跉者への配虑など団地内環境はあまり 評価されていない。すなわち、建設後かなり年数を経た古い公社団 地であることから，周辺環境は豊かであるが内部環境が古いが故の 不満があるという特性をよく反映していることが認められる。

また、図一1に併せて示した団地別に集計した各項目の最大値と 最小值を見ると、どの項目においてもほぼ同じような傾向を示すも のの、<公園の広さ $>$ 、 <駐車場 $>$ 、 <立地の総合評価 $>$ などつ いては差が比較的大きい。これは、交通が不便な立地であるが敷地 に余裕がある郊外型団地と、敷地に余裕がないが交通の便はよい既 成市街地型団地に対応したものと考えられる。すなわち、住民の評 価がそのまま物理的環境を反映しているものと考えると、公社団地 の立地や周辺環境は様々であるのに対し、団地内環境は画一的であ ることが示されていると解釈できる。

（2）重回帰モデルによる住環境評価の分析

評価項目の内、総合評価の回答を目的変数、各設問項目の回答を 説明変数として重回帰分析を行った注 3 )。その結果の一例を図一2 に示す。図一2の<欠損なし>とは，（1）と同様，欠損値がない デー夕のみで分析したものである。この結果より、係数が高いすな わち総合評価への貢献度が高い係数は、<団地全体の景観 $>$ 、<防 犯 >、<生活環境 >などであり、それ以降では順次低減し、<駐車 場＞やく住棟の外観＞などが最も低くなっていることがわかる。こ れらの結果は、（1）の結果を踏まえると、公社団地の住環境評価 としておおむね常識的な結果であると考えられる。ただし、く高齢 者への配慮>に対する係数が低いのは、建替え前の団地のみの回答 データであることが影響した可能性がある。

さらに、比較として各項目の回答を連続值ではなく、カテゴリー

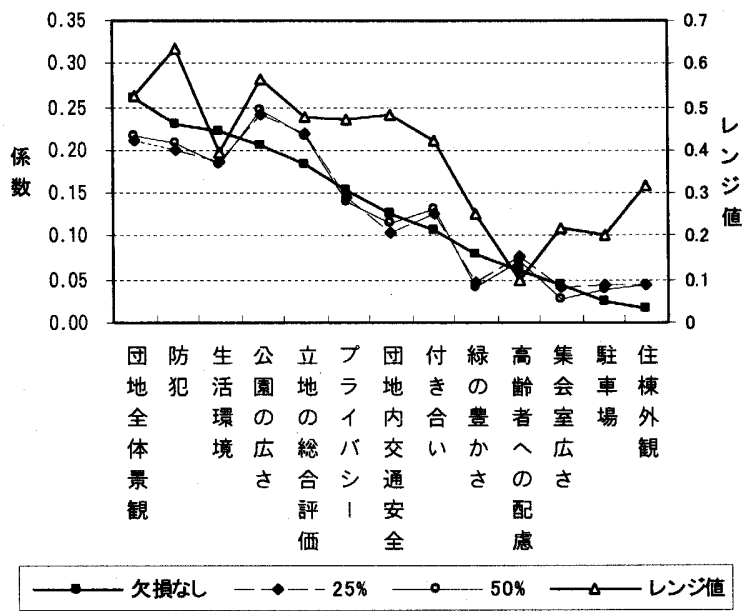

図-2 住環境評価項目の各係数値の比較
値とみて数量化 I 類により分析してみた。算出された各評価項目の レンジ值を図一 2 に併せて示している。レンジ値を見る限り、く防 犯 $>$ が最も寄与が高く、以下、<公園の広さ $>$ 、<団地全体の詈観 >と続くことから、連続値と仮定した重回㷌分析結果と若干傾向が 異なる。しかしながら、係数が高いグループと低いグループという 大きな枠組みではほぼ同じ結果あると言え、全体としての跙龉はな いと考えられる。したがって、住環境評価の回答デー夕は連続変量 として共分散構造分析により分析可能であると判断した。

なお、共分散構造分析では欠損値があるデータが混在していても 推定して分析できる注4)。そこで、25\%欠損（つまり 1 回答者 3 個 まで欠損を許す）と $50 \%$ 欠損（同 7 個）というデータを含めた結 果も図一 2 に併せて示した。欠損値データを含めた分析結果をみる と、久損值を使わない結果と大きな差異はないものの、<公園の広 さ〉とく立地の総合評価＞が高くなっている傾向があるなど若干の 違いが見られる。このように久損値を含めた分析でも差異があまり 見られなかったという興味ある結果が示唆されたが、これらの結果 のみで断定はできないため、以後の分析においては欠損值を含めな いデータのみで分析する。

（3）物理的指標による間接効果を考虑した分析

第一報では、さまざまな物理的指標と魅力度の関係を分析し、第 二報では物理的指標とその住民評価がよく対応しているという結果 を報告している。これらのことから、団地の全体的な魅力を表して いると考えられるく総合評価＞は各項目の評価からだけでなく、物 理的指標からも直接的ならびに間接的に影響を受けているというモ デルが考えられる（図一3）。これは、総合評価に物理的指標が直 接的に影響するのはもちろんのこと、住民評価が物理的指標に間接 的に影響されると考えるモデルである。

ただし、すべての評価項目に対応する物理的指標を設定していな

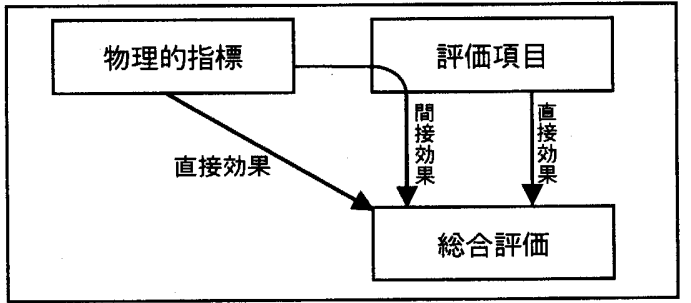

図一3 直接効果と間接効果の説明図

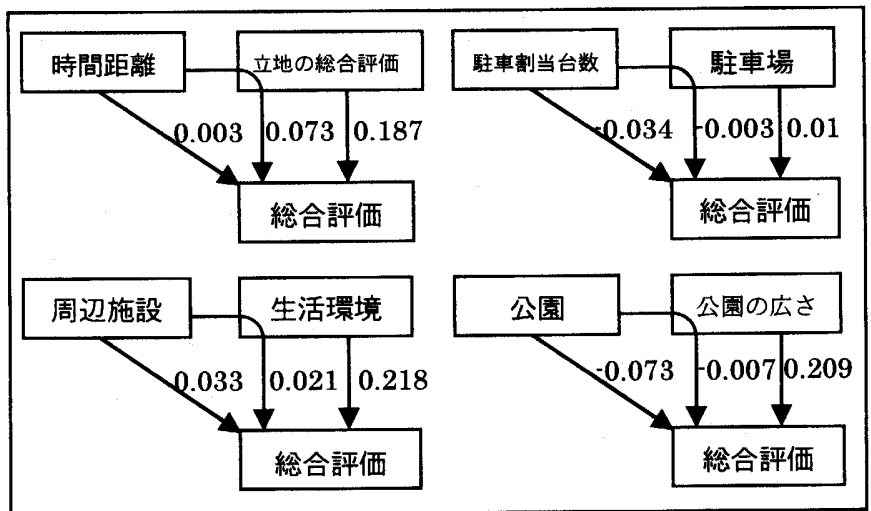

（図中の数值はパス係数值）

図一4 評価項目の直接効果と間接効果 
いので部分的な検証となる。すなわち、第一報で設定したのはく時 間距離 $><$ 駐車割り当て台数 $><$ 周辺施設 $><$ 公園 $>$ の 4 つ物理 的指標である。それをく立地の総合評価 $><$ 駐車場 $><$ 生活環境 $>$ <公園の広さ $>$ の 4 つ評価項目に対応させて分析した。その結果 を図ー4に示す。図中の数值は共分散構造分析の結果として出力さ れたパス係数であり、これが大きいほど総合評価に強く影響を与え ていると解釈される。図一4を見る限り、いずれの評価項目につい ても物理的指標の間接効果ならびに直接効果は、評価項目の直接効 果よりかなり小さいことがわかる。したがって、物理的指標の効果 は認められるにしても、これ以降の共分散構造分析において考慮し なくてもよいことが示唆される。

\section{4. 潜在因子モデルによる住環境評価の分析}

3 章での考察から、以後の分析においては大阪府住宅供給公社居 住者を母集団とし, 用いるアンケート調查デー夕は欠損値のないも のとし、住環境評価モデルとしては物理的指標の効果を考慮しない ものとして分析する。

\section{表一3 因子分析による各項目の因子負荷量}

\begin{tabular}{|c|c|c|c|c|}
\hline & 安全 & 累観 & 機能 & 環境 \\
\hline 寄与率（\%) & 19.5 & 12.2 & 9.2 & 8.9 \\
\hline プライバシー & 0.641 & 0.226 & 0.098 & 0.159 \\
\hline 防犯 & 0.630 & 0.166 & 0.250 & 0.174 \\
\hline 団地内交通安全 & 0.585 & 0.074 & 0.301 & 0.206 \\
\hline 総合評価 & 0.563 & 0.319 & 0.321 & 0.336 \\
\hline 付き合い & 0.534 & 0.045 & 0.129 & 0.137 \\
\hline 生活環境 & 0.506 & 0.233 & 0.037 & 0.373 \\
\hline 住棟外観 & 0.221 & 0.782 & 0.232 & 0.223 \\
\hline 団地全体景観 & 0.196 & 0.765 & 0.245 & 0.259 \\
\hline 集会室広さ & 0.161 & 0.281 & 0.478 & 0.133 \\
\hline 駐車場 & 0.210 & 0.178 & 0.444 & 0.262 \\
\hline 公園の広さ & 0.234 & 0.195 & 0.412 & 0.532 \\
\hline 立地の総合評価 & 0.383 & 0.084 & 0.392 & -0.050 \\
\hline 高齢者への配慮 & 0.478 & 0.237 & 0.362 & 0.060 \\
\hline 緑の豊かさ & 0.200 & 0.245 & 0.075 & 0.617 \\
\hline
\end{tabular}

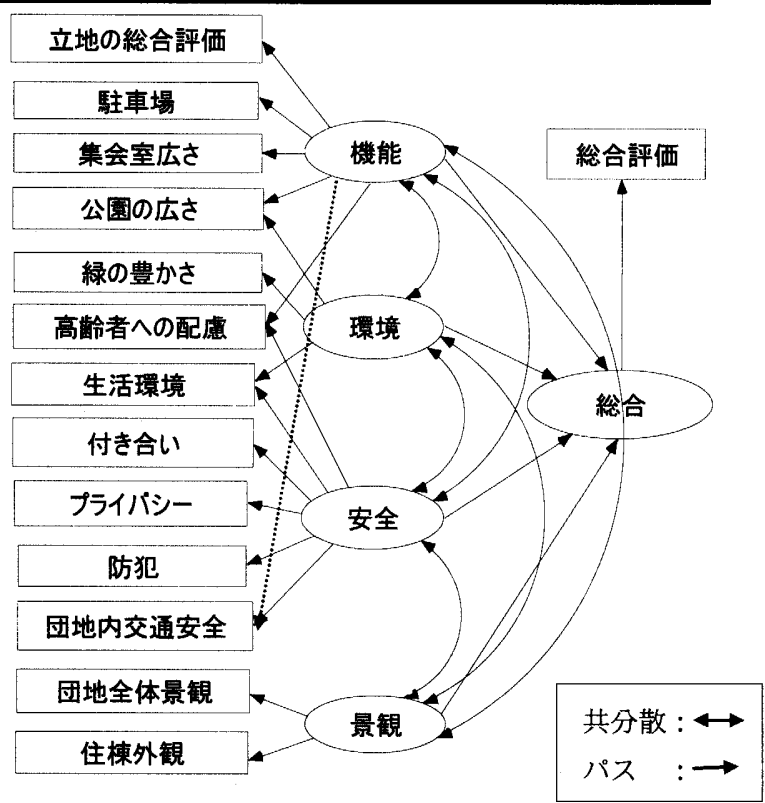

(O内の変数 : 潜在因子、 $\square$ 内の変数 : アンケート評価項目)

図一5＼cjkstart潜在因子を含む住環境評価の構造モデル

\section{（1）因子分析による潜在因子の設定}

まず、構造モデルの構築に必要な潜在因子を因子分析注5)により 特定する。表一3は住環境評価デー夕の因子分析による結果をバリ マックス回転したものである。この表一 3 より、<安全 $><$ 景観 $>$ <機能 $><$ 環境 $>$ という 4 つの因子が抽出できた。これらは図一2 で上位 4 項目をそれぞれ含む因子であり、その意味で代表性が認め られるものと考えられる。

なお，35 年前の梶による因子分析の結果文8)では, 快適度, 保 健度, 安全度, 利便度の順で環境が構造化されるとしており, 本研 究の結果での<安全性>が強く意識されているのとは, 時代背景が 異なっていることが推測される。

\section{（2）潜在因子をもつ構造モデルの構築}

抽出された 4 つの潜在因子に加えて、総合因子という潜在因子を 仮説で設けた構造モデルを考える。そして、表一3の結果に基づい て住環境評価項目と潜在因子をパスにより関連付けたものを図一5 に示す。ただし、この段階のモデル（基本モデル）では図中の潜在 因子間の関係を示す共分散パス（図一 5 の ）は設けていない。

さて、共分散構造分析では、分析結果の一部である修正係数值の 判断によるパスの追加、ならびにワルド検定注 6$)$ による変数の整理 といったモデル修正が可能である。まず共分散の修正係数（表一4 に該当箇所のみ示す）を見ると、4つの潜在変数間の共分散パスの いずれもがモデルの適合性を良くする効果が大であることから、6 力所全ての共分散パスを追加した（図一 5 参照)。そして再度、共 分散構造分析して出力された各係数の修正係数を検討したが、さら に追加するような潜在変数と係数のパスは抽出されなかった。

次に、各評価項目から潜在変数へのパスについて、その必要性を ワルド検定により検討する。表一 5 に示す結果をみると、各パス係 数が有意かどうか（各パスにおける検定統計量が有意差 5 \%水準の 1.96 以下であると有意でない）を見ると、<団地内交通安全く機

\section{表 -4 修正係数の結果}

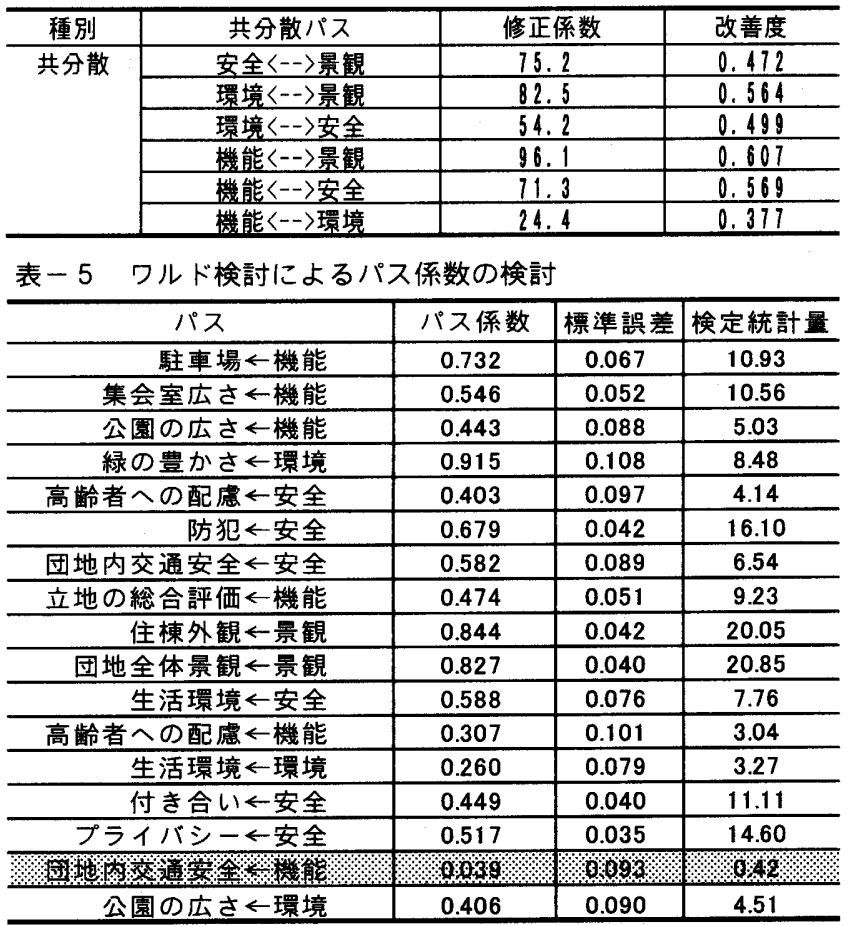


能＞以外はすべて有意であることが示された注7)。そこで、<団地 内交通安全く機能>のパス（図一 5 の点線で示されたパス）のみを 削除した。以上のパス係数ならびに共分散を修正したモデル（以下、 修正モデル）を以降の検討において採用することにする。

\section{（3）修正モデルによる分析結果の検討}

4 つの潜在因子から総合因子へのパス係数を比較すると、4つの 潜在因子の中ではく安全>が最も総合評価に寄与しており (0.602)、 以下、機能 (0.244)、環境 (0.164)、景観 (0.144) となった。こ れは、高齢者が多い公社団地の特性ではないかと推測される。

住環境評価に対する既往論文における共分散構造分析による結果

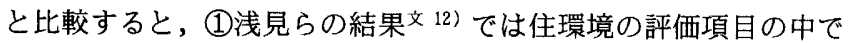
総合満足への影響としてく安全性>が最も高く，以下，快適性，利 便性，保健性と続いていること，(2)斎藤らの結果文 11)でも安全性 に対する評価は満足感に対する評価に大きな影響を与えていること が示されており，昨今の住環境評価における安全性の項目の影響は 強いことが示唆される。

なお、従来の因子分析においては、得られた結果を主観的に解釈 するのみで、検定はほとんどできなかったと言ってよい。一方、共 分散構造分析ではさまざま適合度指標が提案されている。今回の修 正モデルを用いて共分散構造分析した結果においては、RMSE A という指標は 0.05 以下が適合度の観点から望ましいのに対し 0.044、同じくG F I という指標は 0.9 以上が望ましいのに対し 0.962、さらにC F I という指標では 1.0 に近いほど望ましいのに 対し 0.976 である等、分析結果の適合度をあらわす指標値はいずれ も良好であることから、仮説のモデルを棄却できないという意味で 注8)，このモデルは公社団地の住環境評価モデルとして採用できる と考えてよいと判断した。

\section{5. 性別にみた住環境評価}

4 章では全回答者のデータを公社住宅居住者という 1 つの母集団 として分析したが、共分散構造分析では多母集団の同時分析が可能 である。従来の多変量解析では異なる母集団を分析する場合には 別々に分析するしか方法がなく、その際、各係数值が異なるという ことが暗黙に想定されていた。一方、共分散構造分析では、モデル 構造が同一としたままで多母集団の分析が同時にでき、かつ各係数 值が同一かどうかという検定も可能である。そこで、本データを男 女別にグループ化することで，男女それそれを母集団とする多母集 団におけるパス係数の同時分析を試みる。

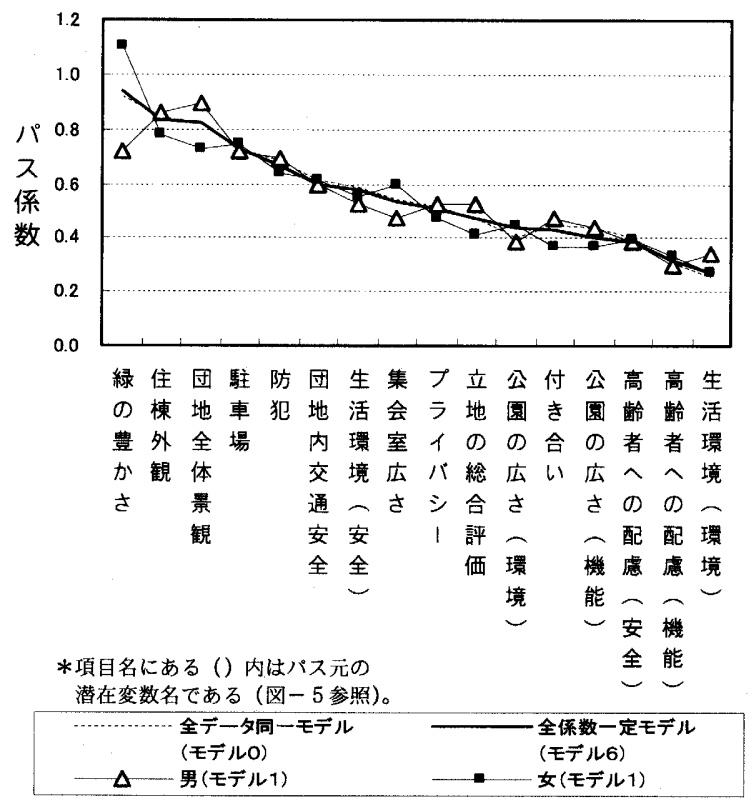

図一6 男女別にみた分析結果パターン

設定したモデル群は以下の通りである。

0 ）男女に分けないモデル：4 章での結果（比較用）

1) 男女で潜在因子が全て別々のモデル（従来の分析手法相当）

2 ) 機能因子に関する係数のみ同一としたモデル

3 ）環境因子に関する係数のみ同一としたモデル

4 ) 安全因子に関する係数のみ同一としたモデル

5 ) 景観因子に関する係数のみ同一としたモデル

6）4つの潜在因子すべての係数を同一としたモデル

表一6に各モデルにおける適合性指標を示す。RMR（データへ の適合度を表す指標）を見ると、データへの適合度は 1 ）の基本モ デルすなわち全ての潜在因子の係数が別々であるというモデルが最 も適合度が高い。これは、パラメー夕数が最も多いことから必然的 にそうなるものであるが、RMSE A（母集団との適合性を表す指 標）やA I Cを見ると、母集団との適合度が最も高いモデルは 6 ) の 4 つの因子全ての係数が同一としたモデルである。したがって、 4 章で述べたことと同様, 仮説のモデルを棄却できないという意味 において, 説明変数については 6) の全ての因子が同一とするモデ ルが良いと判断した。

次に、分散についても検討する。6 ）までのモデルにおける分散

表ー6 各モデルにおける適合度指標值

\begin{tabular}{|c|c|c|c|c|c|c|c|c|c|c|c|c|c|c|}
\hline & \multicolumn{4}{|c|}{ 説明変数の係数 } & \multirow[b]{2}{*}{$\begin{array}{l}\text { 分 } \\
\text { 散 }\end{array}$} & \multicolumn{4}{|c|}{ カイ 2 乗検定 } & \multirow[b]{2}{*}{ GFI } & \multirow[b]{2}{*}{ AGF I } & \multirow[b]{2}{*}{ RMR } & \multirow[b]{2}{*}{ RMSEA } & \multirow[b]{2}{*}{ AIC } \\
\hline モテル番昂 & $\begin{array}{l}\text { 機 } \\
\text { 能 } \\
\text { 性 }\end{array}$ & $\begin{array}{l}\text { 快 } \\
\text { 通 } \\
\text { 性 }\end{array}$ & $\begin{array}{l}\text { 安 } \\
\text { 全 } \\
\text { 性 }\end{array}$ & $\begin{array}{l}\text { 最 } \\
\text { 㘥 }\end{array}$ & & パラメータ数 & カイ 2 乗㯈 & 自由度 & 確率 & & & & & \\
\hline 0:男女同一モテル & & & & & & 40 & 117.36 & 65 & 0 & 0.962 & 0.939 & 0.033 & 0.044 & 197.4 \\
\hline 1:男女別モデル & & & & & & 80 & 181.50 & 130 & 0.002 & 0.943 & 0.907 & 0.041 & 0.031 & 341.5 \\
\hline 2:機能因子同－ & 0 & & & & & 74 & 185.52 & 136 & 0.003 & 0.941 & 0.910 & 0.045 & 0.030 & 333.5 \\
\hline 3:快適因子同一 & & 0 & & & & 76 & 187.49 & 134 & 0.002 & 0.941 & 0.907 & 0.049 & 0.031 & 339.5 \\
\hline 4：安全因子同一 & & & $\mathrm{O}$ & & & 73 & 184.08 & 137 & 0.005 & 0.942 & 0.911 & 0.045 & 0.029 & 330.1 \\
\hline 5：鲸観因子同一 & & & & 0 & & 77 & 187.18 & 133 & 0.001 & 0.941 & 0.906 & 0.052 & 0.031 & 341.2 \\
\hline 6: 全因子同一 & 0 & 0 & 0 & 0 & & 60 & 206.43 & 150 & 0.002 & 0.935 & 0.909 & 0.056 & 0.030 & 326.4 \\
\hline $7:$ 係数 - 分散同一 & 0 & $\mathrm{O}$ & 0 & 0 & 0 & 54 & 209.88 & 156 & 0.003 & 0.934 & 0.911 & 0.059 & 0.029 & 317.9 \\
\hline 的和モテル & & & & & & 210 & 0.00 & 0 & & 1 & & 0 & & 420.0 \\
\hline 独立モデル & & & & & & 28 & 2293.66 & 182 & 0 & 0.362 & 0.264 & 0.325 & 0.167 & 2349.7 \\
\hline
\end{tabular}




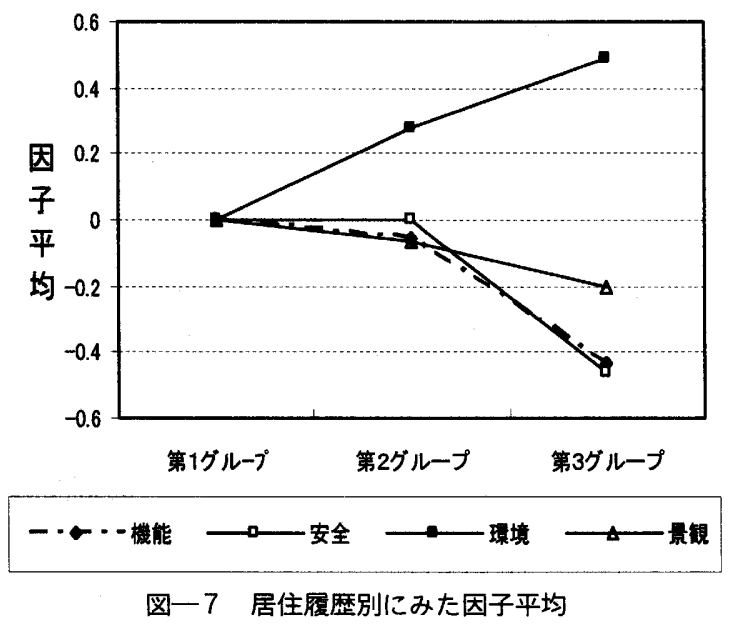

表一7 平均·共分散構造モデルに対する適合度指標

\begin{tabular}{|c|c|c|c|c|c|c|}
\hline & \multicolumn{4}{|c|}{ カイ2乗検定 } & \multirow[b]{2}{*}{ RMSEA } & \multirow[b]{2}{*}{ AIC } \\
\hline モデル番号 & $\begin{array}{c}\text { パラメー } \\
\text { 多数 }\end{array}$ & $\begin{array}{c}\text { カ1 } \\
2 \text { 乗值 }\end{array}$ & 自由度 & 確率 & & \\
\hline 居住歴で因子平均同一モテル & 94 & 398.07 & 263 & 0 & 0.035 & 586.07 \\
\hline 居住歴で因子平均別モテル & 102 & 395.79 & 255 & 0 & 0.036 & 599.79 \\
\hline 軳和モテル & 357 & 0.00 & 0 & & & 714.00 \\
\hline 独立モデル & 84 & 2463.66 & 273 & 0 & 0.139 & 2631.36 \\
\hline
\end{tabular}

は別々であるとしたので、

7 ) 係数は同一、分散も同一としたモデル

を追加し、分析した。その結果を表一6に併せて示している。モデ ル6）と比較してモデル 7 ) は、RMS E A A I Cを見ると母集 団との適合度は高い。すなわち、仮説のモデルを棄却できないとい う意味において，男女別のグループで係数や分散が別々であるとす るモデルを用いる必要はないことが示唆された。ただし，図一6に 参考として示している男女別々のグループとするモデル 1$)$ でのパ ス係数を見ると，いくつかの評価項目のパス係数が男女で異なって いることから，男女でモデル構造は同一であるとしてもパス係数ま で同一かどうかは，今後さらに検討する必要があると判断される。

なお，図一6に示す評価項目のパス係数の大小関係は，図一 2 の ような総合評価と各評価項目が直結しているモデルでの結果と異な っており，むしろ図一1に示す各評価項目の単純集計における大小 関係に近いことがわかる。

\section{6. 居住履歴からみた住環境評価}

共分散構造分析では基本的に分散のみで分析する手法であるから 平均は扱わない。しかし、平均も扱うようにした平均・共分散構造 モデルを使うと平均も考虑できる。

ここでは居住し続けている人々への対策として、居住年数 5 年末 満をく第 1 グループ>、同 5 年以上〜30 年末満をく第 2 グループ

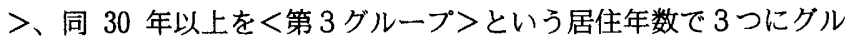
一ピングし、それそれれの公社住宅居住者を母集団とする多母集団に 対する平均・共分散構造分析を試みる注9)。そして、第 1 グループ の因子平均を 0 と固定し、第 $2 、$ 第 3 グループの因子平均を推定す るモデルを考える。図一7に分析により推定されたグループ別の平 均值を示す。表一 7 に示すカイ 2 乗值などの適合度指標からわかる 通り, グループ分けしたモデルの適合度は低いため確実なことは言 えないが、図一7 から示唆されることは以下の通りである。
（1）居住年数が増加すると共に<環境 >因子のみ平均値も増加し ている。つまり、環境因子は居住履歴と共に強く意識されるよう になると考えられる。なお、原田らの結果文9)では 13 年間に “緑・散歩できる場所・公園といった都市の自然アメニティに関 する項目”,で住民の評価構造に大きな構造的変化が見られること を報告している。文 9$)$ は本論文と評価項目も異なり、かつ分析 手法もMS A拡張分析等と異なるので直接の比較はできないが、 （環境＞因子が大きく変化しているという同様の結果を示してい ることは注目に値すると考えられる。

（2）他の 3 指標は第 2 グループすなわち居住 30 年まではほほ横 ばいで、第 3 グループになって低下している。特にく機能 >とく 安全>の低下が著しい。この結果は世代間の差なのか、それとも 居住履歴効果なのかの解釈は難しいが、第 3 グループに属する回 答者の多くは当然のことながら高齢者であることから、高齢者と そうでない世代で居住環境への意識の違いが示唆される。

\section{7. まとめ}

本研究では、大阪府住宅供給公社の貨貸集合住宅団地の再生に関 する前報からの継続研究として、12 の団地の住民に対するアンケ 一ト調査データを用いて、住民による住環境評価の実態と立地特性 の関係を明らかにした。すなわち，本論文では公的賃貸集合住宅団 地に限られるが一般住民を対象に外部環境に絞った評価構造を明ら かにすることを目的に, 時間的な構造変動の分析や既往論文への言 及も含めて共分散構造分析を行った結果を報告した。

以下にその主たる成果をまとめる。

（1）共分散構造分析は、線形モデルにおいて数量化 I 類とほぼ同 様の結果を出すと共に、係数を算出するなど、より優れた分析手法 であることが確認された。その上で、欠損値のあるデータでも支障 がないことの示唆、ならびに間接効果についての示唆を得た。

（2）住環境評価デ一夕を因子分析した結果，大きくく安全 $><$ 機 能 $><$ 環境 $><$ 固観 $>$ という 4 つの潜在因子で説明できることを明 らかにすると共に、それらと評価項目の関係からなる共分散構造モ デルを作成し、適合性を表すさまざまな指標により当該モデルを修 正した上で、最終的なモデルの適合性を示した。これにより住環境 の評価構造が同定されたものと考えられる。なお、4つの潜在因子 の中では、<安全 >が最も総合評価に寄与しており、以下＼cjkstart機能＞ <環境 $><$ 累観 $>$ である。

（3）共分散構造分析の特長である多母集団での分析手法を用いた 結果、公社居住者の男女別々とする住環境に対する共分散構造モデ ルよりも、男女で同一とする共分散構造モデルの方がよりよいと考 えられることを示唆した。

（4）平均・共分散構造分析を用いて、居住年数別の傾向を分析し た結果、4つの潜在因子は居住年数で変化する可能性が示唆された。

以上、団地周辺環境に対する住民の評価構造を明らかにすると共 に、共分散構造分析の適用性を明らかにしたと考える。従来の多変 量解析においては，重回帰分析などを除いては検定が困難であり、 その解釈は多分に分析者に委ねられてきた。しかし、共分散構造分 析による厳密な検定作業ができることで、恣意的な解积を排除でき るものと期待される。

なお今回は、建て替え前の古い団地を対象としたが、新しく建て 
替えた団地における結果と付き合わすことによる住環境評価の構造 分析の精緻化が求められる。また、今回は住環境評価に特化したが、 入居理由や定住性志向などとの比較検討も今後の課題である。さら に、居住歴という時間変化により評価構造が変化する可能性を示唆 したが、今回のアンケート調査だけでは一般化できないので、様々 な地域や団地における調査を積み重ねることも今後の課題としたい。

謝 辞

最後に、アンケートに回答頂いた住民ならびに調查に協力いただ いた大阪府住宅供給公社に感謝の意を捧げます。また，匿名の查読 者から論文構成に有益な意見を頂戴したことに感謝します。

注

1 ) 今回の回収率は $21.6 \%$ と低いが，著者らの経験によると戸別配布・郵送 回収での回収率は 2 割程度であることから，本調查の回収率は殊更䔡い結 果ではない。また，大阪府住宅供給公社が現在管理している賃貸住戸が約 2 万戸であり、その $10 \%$ 強にあたる 2,539 世帯へ配布していることから、 代表性は担保されているものと想定している。

2) 文 6 ）によると選択肢が 5 以上あるものは連続デー夕と見なしてよい。 3 ）共分散構造分析は重回帰分析を含んだモデルであるので、そのまま共分 散構造分析用ソフトにて分析できる。ただし、念のため重回帰分析専用り フトで算定した係数と結果を照合して、両者が一致していることを確認し た。用いたりフトはS P S S 社製あa mo s (Ver4) で、モデルのパラメ 一夕推定法は最尤法を用いている。

4 ) 久損値の扱い方法には一般に, (1)欠賣值がある回答者デー夕は全て使わ ない (リスト単位)、(2)損值のみ排除して他のデー夕は使う (ペア単位) (3)欠損值には平均值を代入する（代入法）などがある。しかし，本論文で 用いたamosでは, 久損值に最尤推定による推定値を代入するという独 自の方法を操用している（詳しくは文 5 )，p.45-46などを参照）。

5 ）共分散構造分析ではいわゆる因子分析（探索的因子分析）も可能である が、ここでは比較のためにあらかじめ設定した構造モデルの適合性検討と いう枠組み（検証的因子分析と呼ばれる）のみ用いる。

6 ）ワルド検定：モデルで設定したパスの中で削除すべきものを見つけるた めの検定方法のひとつ。開発者の Wald にちなんで名が付けられている。 各パスの検定量が標準正規分布の両側 $5 \%$ 以内以上であれば検定は有意に なり，当該パスは必要と判断される沟。

7 ）検定により“有意”であるからと言って，当該バスが直ちにモデルに “必要”であるとは言えず，単にモデルにとって無意味でないと言えるだ けである。しかし，少なくとも“有意でない”ことはモデルに“必要な い”のは確かであるので該当するパスは削除し，それ以外の変数は残して， 以降の分析中でさらに検討するという手順をとった。
8 ) 統計学的には通常, 菓無仮説を立てて，それを棄却するという手順で主 張したい仮説を証明する。しかし, 共分散構造分析は, “仮説を棄却でき ない”という弱い検定しかできない。その意味で，これらの指標が良い值 を示すからといって，当該仮説が正しいという主張は言い過きで，“この 仮説は㶳却できないという意味で採用できる”とする手順をとる。

9 ）平均・共分散構造分析により解析を行う前提としては、共分散構造分析 による多母集団の同時分析が行われていて、少なくとも平均・分散・共分 散が同一であるという測定不変性が確認できていることが求められる文6)。 ここでは、5章と同様にさまざまなモデルについて検証した結果、平均・ 分散・共分散が同じとするモデルの適合性が最もよいことが明らかになっ たことから、この前提が確認できているとみなした。

参考文献

1) LIU Tongtong, 横田隆司, 柏原士郎, 吉村英祐, 飯田 匡: 空屋率等氻 らみた公的貨貸集合住宅団地の立地環境とその評価, 日本建築学会計画 系論文集, No.571, pp.9-16，2003.9

2) LIU Tongtong 横田隆司, 柏原士郎, 吉村英祐, 飯田 匡: 公的貨貸集合 住宅団地の立地・住環境に対する住民評価, 日本建築学会計画系論文集, No. 580, pp.1-8, 2004.7

3 ) 横田隆司, 柏原土郎, 吉村英祐, 飯田 匡, LIU Tongtong : 公的団地 の立地特性と住民の住環境評価の関係について，地域施設計画，Vol.21， pp. $109-114,2003.7$

4) LIU Tongtong : 立地特性及び住環境評価からみた公的貨貸集合住宅団地 の再生の方向性に関する研究一大阪府住宅供給公社の団地を対象として 一, 大阪大学博士 (工学) 学位論文, 2004.3

5 ) 山本嘉一郎, 小野寺孝義編：A m O S による共分散構造分析と解析事例 [第 2版], ナカニシヤ出版, 2002

6 ) 狩野裕, 三浦麻子: グラフィカル多変量解析 (增補版), 現代数学社, 2002

7) 豊田秀樹編：共分散構造分析 [技術編]，朝倉書店，2003

8 ）梶 秀樹：生活環境に対する住民満足感の構造に関する研究, 日本建築 学会論文報告集, No.165, pp.77-84, 1969.11

9 ）原田真幸，久野 覚: 果京 3 地区における居住環境に対する住民意識の 13 年間の変化, 日本建築学会帞画系論文集, No.499, pp.35-42, 1997.9

10）網藤芳男, 村川三郎, 西名大作, 関根範雄 : 大学生の環境移行に伴う生 活環境評価の時間的変化と共分散構造, 日本建築学会計画系論文集, No. 540, pp. $81-88,2001.2$

11）斎藤伊久太郎, 小瀬博之：住民のアメニティ評価構造に対する外部空間 の評価の影響, 日本建築学会計画系論文集, No.561, pp.101-106, 2002.11

12）崔 廷敏，浅見泰司 : 畕貸住宅居住者の満足度評価に見られる遷座的評 価構造, 都市住宅学, Vol.42, pp.86-97, 2003.8

13）崔 廷敏, 浅見泰司 : 居住者満足評価における居住者の価值観, 日本建 築学会計画系論文集, No.576, pp.133-139, 2004.2

（2004年 5 月 10 日原稿受理，2004年 9 月 27 日採用決定） 